\title{
Teologia da Libertação na terra do dólar
}

\section{Liberation Theology in the land of the dollar}

DOI: $10.46814 /$ lajdv2n6-009

Recebimento dos originais: 01/09/2020

Aceitação para publicação: 30/10/2020

\author{
Jorge Claudio Noel Ribeiro \\ Atuação: Pontifícia Universidade Católica de São Paulo \\ Endereço: Rua Cardoso de Almeida 962 ap. 82 São Paulo - SP - 05013-001 \\ E-mail: jorgeclaudio@ olhodagua.com.br
}

\begin{abstract}
RESUMO
Embora pouco conhecida no meio acadêmico latino-americano, a Teologia da Libertação (TdL) nos EUA apresenta uma longa tradição que inspira inovadoras práticas religiosas e sociais. Essa vertente mostra a face mais madura e solidária da religião na sociedade estadunidense, contrapondo-se à corrente mainstream, neopentecostal. Profundamente enraizada na história e cultura estadunidense, a TdL se desdobra em diversas vertentes: é negra, feminista (ou "womanist", na versão negra), hispânica, asiática, haitiana, nativo-americana e "queer".

Ao longo de sua história, a TdL dos EUA apresenta três eixos principais. O primeiro são as Black Churches, que desde o século 18 se opunham à escravidão e à segregação dos afro-americanos que, após a abolição da escravidão se transformaram nas infames leis "Jim Crow". A luta contra essa legislação foi religiosamente inspirada e mobilizou líderes e associações.

$\mathrm{O}$ segundo eixo foi a Harlem Renaissance (HR), amplo movimento artístico durante o qual numerosos intelectuais e artistas afro-americanos apresentaram expressiva produção. Embora não seja formalmente teológico, por sua contribuição à formação da identidade afro-americana, esse movimento é apontado como importante componente da TdL nos EUA.

O terceiro eixo foi o movimento pelos Direitos Civis cujo berço foi a resistência e a luta contra a escravidão. A Marcha sobre Washington, de 1963, é referência inescapável na luta pelos direitos civis. Conclamada por várias associações e igrejas, reuniu 250 mil pessoas. Na ocasião, King proferiu seu clássico discurso "Eu tenho um sonho". A marcha acelerou importantes mudanças em tramitação no Congresso que culminaram na legislação anti-segregação no início dos anos 1960 e na eleição de Barack Obama em 2008.
\end{abstract}

Palavras-chave: teologia, libertação, Estados Unidos, Black Churches, Harlem, Direitos Civis.

\begin{abstract}
Although little known in Latin American academic circles, Liberation Theology (TdL) in the USA has a long tradition that inspires innovative religious and social practices. This aspect shows the more mature and solidary face of religion in American society, in contrast to the mainstream, neoPentecostal current. Deeply rooted in American history and culture, TdL unfolds in several aspects: it is black, feminist (or "womanist", in the black version), Hispanic, Asian, Haitian, Native American and "queer".

Throughout its history, the TdL of the USA has three main axes. The first are the Black Churches, which since the 18th century have opposed slavery and the segregation of African Americans who,
\end{abstract}


after the abolition of slavery, became the infamous "Jim Crow" laws. The fight against this legislation was religiously inspired and mobilized leaders and associations.

The second axis was the Harlem Renaissance (HR), a wide artistic movement during which numerous intellectuals and African-American artists presented expressive production. Although not formally theological, for its contribution to the formation of African-American identity, this movement is identified as an important component of TdL in the USA.

The third axis was the Civil Rights movement whose cradle was resistance and the fight against slavery. The 1963 Washington March is an inescapable reference in the struggle for civil rights. Called by various associations and churches, it gathered 250 thousand people. On that occasion, King delivered his classic speech "I have a dream". The march accelerated important changes in progress in Congress that culminated in anti-segregation legislation in the early 1960s and the election of Barack Obama in 2008.

Keywords: theology, liberation, United States, Black Churches, Harlem, Civil Rights.

\section{INTRODUÇÃO}

A Teologia da Libertação (TdL), tendência que une religião e luta por justiça social, surgiu na América Latina, a partir do final da década de 1960, no âmbito do catolicismo e, nos Estados Unidos apresenta uma longa tradição nos campos protestante, católico e das lutas sociais.

A importância do estudo da Teologia da Libertação (TdL) nos EUA se deve a vários motivos. Primeiro: não obstante sendo surpreendentemente pouco conhecida no meio acadêmico fora dos EUA, há neste país uma intensa elaboração teológica e inovadoras práticas religiosas que seguem a linha da libertação. É importante resgatar essas experiências, pois mostram uma face mais madura e solidária da religião nessa sociedade. Mais famosa, a vertente mainstream, neopentecostal caracterizada pelo estilo midiático e emocional, pelo peso político-partidário e pelo viés fundamentalista - influencia as manifestações mais ruidosas do pentecostalismo no Brasil, cujo crescimento se acelerou a partir da década de 1970, tornando-se um fator decisivo na atual revolução do cenário religioso e da sociedade brasileira.

Segundo motivo para pesquisar as vertentes teológicas da libertação praticadas na sociedade estadunidense é que elas fornecem contraponto para as sociedades latino-americanas. Assim, nos EUA a TdL se enraíza principalmente em solo protestante, que é mais descentralizado do que o campo católico atual, o que permite antever tendências futuras.

Terceiro motivo para o estudo da TdL em geral é a retomada da memória de dois eventos revolucionários no âmbito do catolicismo. O primeiro evento foi o Concílio Vaticano II (1962-65). Nessa reunião de extraordinária magnitude, a Igreja Católica se dispôs a rever sua estrutura e procedimentos, pretendeu dialogar com a Modernidade, com as questões contemporâneas (aggiornamento) e estabelecer laços com outras religiões (ecumenismo). Segundo evento, e um dos 
desdobramentos do Concílio, foi a ascensão da Teologia da Libertação na América Latina, assumida oficialmente na II Conferência Geral do Episcopado Latino-Americano, em Medellín em 1968. No entanto, nas décadas transcorridas até o advento do Papa Francisco, essa perspectiva progressista foi seguidamente desconstruída pela alta hierarquia e por grupos católicos conservadores que ganharam evidência durante o pontificado dos papas João Paulo II e Bento XVI.

Teologias, no plural - Profundamente enraizada na história e cultura dos EUA, a TdL estadunidense se desdobra em diversas vertentes principais: ela é negra, feminista (ou “womanist”, na versão negra), hispânica, asiática, haitiana, nativo-americana e "queer". Também há ensaios de Teologia da Libertação judaica, palestina e islâmica. Teoricamente progressista e comprometida com o ativismo relacionado a causas próprias de cada grupo que a pratica, mas também as gerais (como os direitos civis), a TdL estadunidense apresenta pontos de confluência com a vertente latino-americana, sua referência assumida, em vários aspectos.

A TdL estadunidense se filia ao pensamento e ação de figuras notáveis, tais como Charles A. Briggs, os irmãos Reinhold e Richard Niebuhr, Dietrich Bonhoeffer, Paul Tillich, Martin Luther King, Malcolm X, James H. Cone, Richard Horsley e Alice Walker. Esses intelectuais, artistas e ativistas tiveram ou têm estreitos laços com comunidades religiosas e/ou instituições acadêmicas dos EUA, com destaque para o Union Theological Seminary (UTS), afiliado à Columbia University em Nova York.

\section{BLACK CHURCHES}

Nascida no século XVIII, importante tendência da TdL dos EUA foi gestada nas Black Churches que se opunham à escravidão e à segregação dos afro-americanos. O termo Black church se refere a denominações cristãs voltadas para os negros daquele país. Enquanto algumas dessas igrejas pertencem predominantemente a denominações negras, como a Igreja Episcopal Metodista Africana (AME), muitas igrejas negras integram denominações brancas mais amplas.

A maioria das primeiras igrejas negras, formadas antes de 1800 tanto no Norte como no Sul estadunidense, foi fundada por ex-escravos. Essa época é conhecida como o segundo Avivamento ou Grande Despertar (1790-1840), em que pregadores das igrejas Batista e Metodista viajaram por todo o Sul, dirigindo-se diretamente aos escravos, o que suscitou numerosas conversões.

O racismo, especialmente no Sul, impedia os negros de participar dos cultos nas igrejas dos brancos. Em 1792, na Filadélfia, uma igreja negra nasceu de um protesto revolucionário. Após membros negros da Igreja Metodista de São Jorge serem retirados à força de uma galeria que eles mesmos haviam construído, sob a liderança dos pregadores Absalom Jones e Richard Allen, esses 
membros deixaram essa igreja e fundaram a Igreja Betel. Dois anos depois, a congregação negra já havia construído um templo novo, sob o lema "Para buscar por nós mesmos". Em reconhecimento à liderança e pregação de Richard Allen, em 1799 o bispo britânico Francis Asbury ordenou-o pastor metodista. Descobrindo que outras congregações negras na região buscavam a independência do controle dos brancos, em 1816, Allen organizou uma nova denominação, a Igreja Africana Metodista Episcopal (AME), a primeira a ser totalmente independente. Naquele ano, Allen foi eleito seu primeiro bispo.

No período pré-Guerra Civil, as congregações batistas negras já haviam crescido rapidamente nas cidades: eram lideradas por negros livres ao passo que a maioria de seus membros era de escravos. Nas zonas rurais, os escravos organizavam encontros religiosos secretos, numa "igreja invisível", ou subterrânea, em que misturavam cristianismo com crenças e ritmos africanos. Inspirados neles, os hinos metodistas se transformaram em spirituals, que propiciavam identidade religiosa, conforto e uma forma própria de comunicação e resistência aos afro-americanos ${ }^{1}$.

Em 21 de agosto de 1831, ocorreu uma rebelião de escravos na Virgínia liderada por Nathaniel Turner, jovem escravo religioso que era visto frequentemente em jejum e oração, imerso na leitura da Bíblia. Relatava visões, em que recebia mensagens de Deus. Da revolta resultaram 60 mortes de brancos. Turner foi condenado à morte e enforcado. Sucederam-se 56 execuções, além de um número superior a 200 negros terem sido mortos em embates com milícias brancas. Além da Virgínia, outros estados do Sul adotaram leis que proibiam educação dos escravos e negros livres, restringiam os direitos de reunião e exigindo, nos cultos negros, a presença de ministros brancos, os quais usavam o texto bíblico para justificar o status quo escravagista e reforçar a submissão dos escravos a seus senhores, prometendo que os escravos leais seriam recompensados na vida após a morte. Às vezes, os escravos organizavam escolas para estudar as Escrituras. Havia um trabalho de alfabetização dos negros do qual participou, quando jovem escravo, o futuro político e escritor Frederick Douglass.

Após a abolição da escravatura (1865), os libertos continuaram a fundar templos que também funcionavam como escolas e desenvolveram atividades como o atendimento a indigentes, orfanatos e ministérios nas prisões. Daí resultaram fortes organizações comunitárias, lideranças religiosas e políticas que se destacaram, mais tarde, nos movimentos pelos direitos civis. Essas igrejas criaram uma forma poderosa do cristianismo que sincretizava tradições religiosas africanas.

Nessa época, as igrejas do Norte, tanto as fundadas por negros livres como as denominações controladas por brancos, enviaram missões ao Sul para atrair e alfabetizar os recém-libertos. No

\footnotetext{
${ }^{1}$ RABOTEAU, A. Slave Religion (passim)
} 
primeiro ano após a guerra, a AME atraiu 50 mil fiéis. Até o final da Reconstrução, essa denominação mantinha congregações desde a Flórida até o Texas. A Igreja Zion AME Independente, fundada em Nova York, também abrigou dezenas de milhares de membros do Sul.

Ao mesmo tempo, as igrejas batistas negras no Sul, já solidamente estabelecidas antes da Guerra Civil, continuaram a crescer. Assim, em 1895, seus líderes organizaram a Convenção Batista Nacional, resultante da unificação de três convenções nacionais negras, organizadas na década anterior. Essa convenção reunia atividades de missão, educação e cooperação global e, hoje, é a maior organização religiosa negra nos Estados Unidos.

Por volta de 1870, consolidou-se uma experiência precursora, quando protestantes progressistas, sobretudo brancos, criaram o movimento denominado Evangelho Social, que defendia a reforma social-religiosa em resposta aos problemas sociais criados a partir da Guerra Civil, pela rápida industrialização, urbanização e imigração crescente. Esse movimento defendia a aplicação de princípios morais na melhoria da sociedade industrial e a implantação de reformas como a abolição do trabalho infantil, a redução da jornada de trabalho e a regulação das fábricas. Os militantes do Evangelho Social priorizavam a salvação social e se baseavam nas nascentes ciências sociais e na teologia liberal. Esse movimento atingiu o ápice no início do século XX.

A luta contra as leis segregacionistas, reunidas sob o rótulo de "Jim Crow", culminou nas décadas de 1950-60 com o movimento pelos Direitos Civis, liderado pela NAACP (National Association for the Advancement of Colored People) e por figuras como o pastor Martin Luther King, tendo-se consolidado teoricamente através da TdL Negra. Décadas mais tarde, a eleição de Barack Obama, em 4/11/2008, mobilizou aspirações e conquistas de igualdade social. A oposição a Obama inquiriu sobre suas raízes religiosas e "denunciou" seu mentor, o incendiário pastor Jeremiah Wright, da Trinity Church em Chicago, que se inspira nessa vertente teológica.

Atualmente, as igrejas negras continuam a ser uma fonte de apoio para os membros da comunidade afro-americana. Elas tendem a se concentrar em questões como a pobreza, violência de gangues, uso de drogas, atuação nas prisões e racismo. A maioria das pesquisas indica que, embora os negros tendam a votar no Partido Democrata, os membros de igrejas negras são mais conservadores em questões sociais do que o conjunto dos protestantes brancos. 


\section{HARLEM RENAISSANCE ${ }^{2}$}

Harlem Renaissance (HR), ou Renascença do Harlem, é o nome dado a um amplo movimento artístico (sobretudo literário, musical e das artes plásticas) e também ensaístico durante o qual um grupo de artistas afro-americanos apresentaram expressiva produção ${ }^{3}$. Embora não seja formalmente teológico, por sua contribuição à formação da identidade afro-americana, esse movimento é apontado como importante componente da TdL nos EUA.

A HR se situa entre o final da I Guerra Mundial e pouco depois da Depressão de 1929. Além do aspecto artístico, incluiu a consciência racial, a "volta para a África". O ensaísta W.E.B. Du Bois, um dos fundadores da National Association for the Advancement of Colored People (NAACP, ou Associação Nacional para o Avanço das Pessoas de Cor), desenvolveu a noção de "dualidade", que marca a consciência dividida da identidade negra, entre ser americano e negro, duas almas, dois pensamentos, duas moções inconciliáveis: dois ideais em guerra em um só corpo escuro, cuja força tenaz é o que o impede de se dilacerar ${ }^{4}$.

Algumas questões permearam a Renascença do Harlem: a influência da experiência da escravidão e das tradições populares afro-americanas sobre a identidade negra, os efeitos do racismo institucional, os dilemas decorrentes de fazer apresentações artísticas para a elite branca e a transmissão da vida moderna negra no Norte urbano.

A HR representou uma etapa de insersão da experiência negra na história norte-americana, tanto cultural como geopolítica. Ela nasceu a partir das transformações sofridas pela comunidade afro-americana, depois da abolição da escravatura e da expansão das comunidades do Norte. Nessa época, os negros emancipados começaram a lutar em prol da participação cívica, igualdade política, econômica e cultural, contra as leis segregacionais Jim Crow e contra a ação assassina da Ku Klux Klan. As dificuldades da vida no Sul provocaram a migração crescente dos afro-americanos para o Norte industrializado. Durante a parte inicial do século 20, o bairro novaiorquino do Harlem foi o destino de migrantes negros de todos os EUA. O esforço de guerra resultou em enorme demanda por trabalho industrial não qualificado e atraiu as pessoas das áreas rurais, dando origem a uma nova cultura de massas. Terminado o conflito, muitos soldados afro-americanos que lutaram em unidades

\footnotetext{
2 HUGGINS, Nathan I. Harlem Renaissance: an Assessment. NY: Oxford UP, 1971. Ver também: http://www.loc.gov/rr/program/bib/harlem/harlem.html\#top

${ }^{3}$ Só para citar alguns, dentre várias dezenas, participaram do movimento o escritor e poeta Langston Hughes, o ator Paul Robeson e os músicos e cantores Louis Armstrong, Josephine Baker, Duke Ellington, Ella Fitzgerald, Dizzy Gillespie, Earl Hines, Billie Holiday e Thelonious Monk

${ }^{4}$ DU BOIS, W.E.B. The souls of black folk; The dusk of dawn (passim)
} 
segregadas ao voltar, se depararam com uma nação que, com frequência, não reconhecia suas realizações.

A primeira fase da Renascença do Harlem começou em 1917, com a estréia de Três Peças para um Teatro Negro. Escritas pelo dramaturgo branco Ridgely Torrence, apresentavam personagens afro-americanos dotados de complexas emoções humanas e anseios, rompendo com estereótipos e caricaturas sobre os negros. Em 1917, Hubert Harrison, "o pai do radicalismo do Harlem", fundou a Liga da Liberdade e A Voz o primeiro jornal do "Novo Movimento Negro". Outro marco foi o soneto, If We Must Die, publicado em 1919 pelo poeta Claude McKay.

Um novo estilo pianístico chamado Stride Harlem aproximou os negros pobres da elite negra e representou uma mudança na banda de jazz tradicional do sul, que era composta principalmente de instrumentos de sopro, enquanto o piano era considerado instrumento da elite. Entre os lendários músicos de jazz havia pianistas muito talentosos, com destaque para a figura gigante de Duke Ellington. Nessa época, o estilo musical dos negros atraiu cada vez mais romancistas, dramaturgos e compositores brancos que incorporaram as tendências musicais e temas afro-americanos em suas obras. Eles usaram poemas de poetas negros como letra de suas músicas e compuseram concertos inspirados nos blues, spirituals e jazz.

Muitos brancos viam a cultura negra norte-americana da época como algo "oriundo da natureza" e que estimulava sua liberdade criativa. O interesse na vida dos afro-americanos também gerou óperas como Porgy and Bess, de George e Ira Gershwin e DuBose Heyward, representadas só por atores negros, e Quatro Santos em Três Atos, de Virgil Thomson e Gertrude Stein. A HR criou oportunidades para escritores negros serem publicadas por editoras tradicionais.

Um dos destaques na área artística foi Paul Robeson, renomado ator no teatro e no cinema, atleta, cantor e escritor. Em 1930, ele interpretou o Otelo, de Shakespeare, em Londres e, mais tarde, foi o primeiro ator negro a fazer esse papel na Broadway. Robeson abriu as portas para outros atores negros, tais como Sidney Poitier e Harry Belafonte. No auge da fama, tornou-se ativista político contra o fascismo e o racismo. Socialista, foi perseguido pelo macartismo e seu arquivo no FBI é um dos mais extensos já produzidos sobre um artista. Em 1939, Billie Holiday estreou sua carreira com a música Strange Fruit, um protesto contra os linchamentos, de autoria do judeu Abel Meeropol, que até hoje faz enorme sucesso.

A HR situou a experiência negra no interior da história cultural americana e também redefiniu a visão sobre os afro-americanos, nos EUA e no cenário mundial. Mudou-se a imagem dos rústicos camponeses negros, migrados do sul, para pessoas sofisticadas, cosmopolitas. Essa nova identidade 
levou a uma consciência social ampliada, fazendo com que os afro-americanos expandissem internacionalmente seus contatos intelectuais e sociais.

Não obstante suas realizações, a HR foi acusada de provincianismo étnico. Ao proclamarem uma nova consciência racial, seus atores acabaram por mimetizar as roupas e maneiras dos brancos sofisticados, perdendo a identificação com suas raízes. Além disso, o movimento ostentava uma fé ingênua na democracia americana, crença na arte e literatura como agentes de mudança, sem conexão com as realidades econômicas e sociais. Esse otimismo tornou os intelectuais negros despreparados para o impacto da Grande Depressão, que precipitou o fim da Renascença do Harlem. Entretanto, por sua imensa repercussão e duradoura influência, esse movimento lançou as bases do Movimento dos Direitos Civis, no pós-Segunda Guerra.

\section{MOVIMENTO PELOS DIREITOS CIVIS 5}

O movimento pelos Direitos Civis tem uma longa história que remonta aos inícios do século 19 e teve como eixo a resistência e a luta contra a escravidão negra, condição esta que não foi aceita pelos ramos do protestantismo como os quakers e menonitas. Uma dinâmica social pujante construiu uma cultura de libertação, berço da teologia negra ${ }^{6}$.

Em 1827 começou a ser publicado o Freedom's Journal; quatro anos depois surgiu o semanário Liberator. Em 1830 já havia 300 mil afro-americanos livres e seus representantes se reuniram na primeira National Negro Convention, a que se seguiram outras oito convenções.

Um marco na consolidação da consciência negra foi a publicação, em 1852, do romance de inspiração abolicionista A cabana do Pai Tomás, de Harriet Beecher Stowe, o best seller do século. Figuras marcantes nesse movimento são Frederick Douglass, jornalista e parlamentar negro, e o branco John Brown, considerado mártir abolicionista, que foi enforcado após comandar, em 1859, um assalto malsucedido a um arsenal federal com objetivo de obter armas para libertar negros. $\mathrm{Na}$ época anterior à Guerra Civil, montou-se a Underground Railroad, uma rede que contrabandeava os fugidos das fazendas do Sul os ajudava a se transferirem para o Norte. A ex-escrava Harriet Tubman destacou-se como "condutora" de libertos.

Em decorrência da Proclamação de Emancipação de Lincoln, de 1863, a Guerra Civil contou com a participação de 180 mil negros, na maioria ex-escravos, que aderiram aos exércitos da União. Entretanto, eles eram tratados mais como trabalhadores braçais do que soldados e viviam em piores

\footnotetext{
${ }^{5}$ DUNAWAY, F. A Teologia Negra: uma Introdução.

${ }^{6}$ CARSON, Clayborne. Civil Rights Chronicle - the African-american struggle for freedom. Lincolnwood: Legacy, 2003. Pesquisa realizada em janeiro/2013 no Schonburg Center for Research in Black Culture de Nova York, no bairro do Harlem. Ver: http://www.nypl.org/locations/schomburg.
} 
condições que os demais. Para os afro-americanos, as guerras seguintes, sobretudo as mundiais, foram oportunidade de ascensão e de integração dentro da sociedade estadunidense branca. Em 1866, logo após o conflito civil, veteranos confederados fundaram a Ku Klux Klan, que passou a realizar numerosos linchamentos de negros; seu crescimento foi tão grande que em 1920 atingia 4 milhões de afiliados, que chegaram a fazer uma marcha na capital federal reunindo 40 mil pessoas. Entre 1889 e 1918, foram documentados 2.522 linchamentos.

No terreno político-parlamentar, em 1872, P.B.S. Pinchback foi eleito o primeiro governador afro-americano; mas a cada avanço democrático correspondia uma reação, tanto que em 1880 foram sendo implantadas no Sul inúmeras leis segregacionistas reunidas sob a alcunha de Jim Crow - um personagem caricato de negro introduzido em espetáculos populares a partir de 1830 e representado por Thomas Rice, ator branco que se pintava de preto. Nesse período, a segregação ("separados, mas iguais", princípio consignado em leis e aprovado por diversas decisões da Suprema Corte) se infiltrava em detalhes do cotidiano, como bebedouros, restaurantes, igrejas e até mesmo em cemitérios diferentes para brancos e para negros - nesses, muitos túmulos sequer eram identificados; enquanto os negros de qualquer idade eram chamados de "boy" pelos brancos, estes só aceitavam o tratamento de "mister" por parte dos negros. As leis Jim Crow foram contestadas por frequentes ações nas ruas e nos tribunais, sendo oficialmente revogadas pelo Civil Rights Act de 1964 e pelo Voting Rights Act de 1965.

As péssimas condições de vida determinaram intensa movimentação populacional. Houve até projetos de retorno à África e, no Oeste dos EUA, foram fundadas cidades exclusivamente negras. Entre 1916 e 1930, quase 2 milhões de afro-americanos migraram do Sul para o Norte.

Paralelamente, a sociedade civil negra se organizava em associações, como a National Association for the Advancement of Colored People, co-fundada em 1909 pelo combativo W.E.B. Du Bois, também editor do jornal The Crisis. Em 1925 surgiu a atuante Brotherhood of Sleeping Car Porters, criada pelo importante líder A. Philip Randolph; além delas, o National Council of Negro Women, fundado em 1935 pela educadora Mary McLeod Bethune, conselheira negra do presidente Franklin Roosevelt (1933-1945).

Nos esportes, que conferiam enorme visibilidade e identificação a seus atletas, destacaram-se inicialmente os negros Jesse Owens, que conquistou quatro medalhas nas Olimpíadas de Berlim (1936), em pleno regime nazista e, em 1938, o pugilista Joe Louis, que venceu o "super-homem ariano" Max Schmeling. Na década de 40, o negro Jackie Robinson impôs-se ao seleto grupo de jogadores de beisebol, até então exclusivamente branco. Como visto, na área artística, a Renascença do Harlem fornecera plataforma para lançamento de inúmeros artistas negros. 
$\mathrm{Na} 2^{\mathrm{a}}$ Guerra, os afro-americanos compunham $9 \%$ do efetivo militar, mas continuavam a não serem considerados competentes para a ação em combates; no entanto o batalhão de pilotos negros, o Tuskegee, contradisse isso e tornou-se uma lenda. Como nos conflitos anteriores, nesse momento, enormes levas de migrantes do Sul foram atraídas para as fábricas do Norte e se urbanizaram. As comunidades negras e os ex-combatentes exprimiram seu desalento quando, depois de terem contribuído com seu sangue para reconstruir democracias e acabar com o colonialismo, presenciaram no próprio país um cenário em que eram oprimidos. Três anos depois de terminada a $2^{\mathrm{a}}$ Guerra, o presidente Truman dessegregou as forças armadas e criou o President's Comitee on Civil Rights.

A resistência ativa às leis Jim Crow produziu momentos culminantes. Um dos mais antigos ocorreu em 1892, quando Homer Plessy, articulado ao Comitê dos Cidadãos, afrontou a lei que impedia negros de ocuparem lugares de brancos nos trens em Nova Orleans - o caso foi à Suprema Corte em 1896, que condenou Plessy. Em 1944, a negra Irene Morgan ocupou no ônibus um lugar destinado a brancos e, em consequência, foi presa - em 2001, ela foi condecorada pelo presidente Clinton. O gesto de Morgan foi precursor do protagonizado por Rosa Parks, em Montgomery, Virginia, em 1955. À prisão de Rosa, militante jovem da NAACP, seguiu-se um boicote liderado pelo pastor Martin Luther King, então com 26 anos. Em 1956 houve outro boicote aos ônibus segregados em Tallahassee, Flórida. Como consequência, a Suprema Corte americana acatou as reivindicações dos ativistas e terminou com a discriminação no sistema de transportes públicos.

Outro alvo de resistência, muito intensa e generalizada, foram as escolas segregadas. O ponto de partida ocorreu em 1954, no julgamento Brown x Board of Education, em que a Suprema Corte dessegregou as escolas públicas, dando ganho de causa ao rev. Oliver Brown que defendeu o direito de suas duas filhas frequentarem uma escola para brancos. Em 1957, destaque para o episódio dos Nove de Little Rock no qual foi necessária a intervenção da Guarda Nacional para que estudantes negros pudessem comparecer às aulas numa escola pública - intensamente hostilizados por pais e colegas, esses jovens contaram com apoio de uma mentora, Elizabeth Eckford, e da NAACP. Como reação, houve cidades que fecharam suas escolas públicas dessegregadas por um período de até cinco anos. Nessa época, 42 estados proibiam casamentos inter-raciais, havia segregação de moradia e os negros eram obrigados a viver em guetos situados em regiões com precária infraestrutura. Por sinal, Nat King Cole, já famoso cantor nos principais palcos do país, enfrentou a segregação quanto foi morar numa vizinhança branca.

Os anos 60 presenciaram a explosão de sit-ins em que, acompanhados de seus colegas brancos, universitários negros ocupavam restaurantes segregados e impunham sua presença até que fossem atendidos, o que frequentemente não ocorria, ou demorava muito tempo. A grande estrela 
dessa época foi o pastor Martin Luther King, que em 1959 havia viajado à Índia e desenvolvido intenso contato com grupos que praticavam a não-violência ativa, ou satyagraha. Ele liderou várias marchas de protesto e manifestações pacíficas em defesa dos direitos iguais entre brancos e negros, das quais a mais emblemática foi a Marcha sobre Washington por Trabalho e Liberdade, de 28/8/1963, liderada por várias associações e igrejas e que reuniu 250 mil pessoas. Na ocasião, King proferiu seu clássico discurso "Eu tenho um sonho"”. A marcha acelerou importantes mudanças na legislação dos direitos civis e que estavam em tramitação no Congresso. King havia sido preso vinte vezes, mas em 1964 recebeu o Prêmio Nobel da Paz. Foi assassinado em abril de 1968 e a data de seu nascimento, 15 de janeiro de 1929, foi declarada feriado nacional.

Mas nem tudo foi não-violência nas lutas pelos direitos civis. Eram frequentes os conflitos de rua entre brancos e negros, com saques e mortes, como o Red Summer de 1919, ocorrido em mais de 30 cidades. Nos anos 60, Malcom X, líder da Nação do Islã, pregava que os brancos eram inimigos e defendia uma sociedade negra separada. Peregrinou por Meca e retornou mais tolerante, o que não impediu seu assassinato em 1965, por adversários negros. Em 1966, Huey Newton e Bobby Seale fundaram o partido dos Panteras Negras, cujo objetivo inicial era patrulhar guetos negros para protegê-los da brutalidade da polícia. Os Panteras tornaram-se um grupo revolucionário marxista que defendia o armamento de todos os negros, sua isenção de impostos e de todas as sanções da "América Branca", a libertação de todos os negros da cadeia, e o pagamento de compensação aos negros por séculos de exploração branca. Após inúmeros revezes, o partido se desfez em meados dos anos de 1980.

A Marcha sobre Washington de 1963 continua a ser uma referência paradigmática na luta pelos direitos civis; em 1993 realizou-se nova marcha para comemorar os trinta anos daquele evento. A eleição e a reeleição de Barack Obama, em 2008 e em 2012, são consideradas o ápice do movimento dos direitos civis e também da Teologia da Libertação nos EUA.

\section{TEOLOGIA NEGRA}

No contexto das Black Churches, da Harlem Renaissance e da luta por Direitos Civis nasce e se desenvolve o pensamento de James Hal Cone, um dos principais formuladores da Teologia da Libertação Negra, inaugurada em seus livros Black Theology and Black Power (1969) e A Black Theology of Liberation (1970). O pensamento de Cone vem inspirando gerações de teólogos(as) e ativistas, como a teóloga Jacquelyn Grant e o filósofo e ensaísta Cornel West. Apoiando-se na

\footnotetext{
${ }^{7}$ Ver o belíssimo ensaio fotográfico de FREED, Leonard. This is the Day - the march on Washington, com notas de Michael Eric Dyson
} 
reflexão do filósofo e teólogo Paul Tillich (1886-1965), também professor do Union Theological Seminary (UTS), o próprio Cone enfatiza a ideia de que a teologia está enraizada em determinadas razões históricas e sociais, e critica a teologia abstrata de tradição europeia. As bases da TdL de Cone são o contexto de opressão sobre os negros e identificação de Jesus com os pobres e oprimidos. A Teologia da Libertação Negra denuncia os Estados Unidos como uma nação branca e racista, e acusa as igrejas brancas de serem o Anticristo.

A leitura de $O$ Deus dos oprimidos ${ }^{8}$, de Cone, fornece arcabouço conceitual para entender a Teologia da Libertação nos EUA. Seu primeiro enfoque é sociológico-histórico. O autor se deixa impactar por um ponto de partida nascido de sua biografia pessoal, familiar e grupal: a chaga ainda hoje latejante da escravidão cujas consequências motivam as lutas por direitos ${ }^{9}$. Essa é a nota básica, a "clave" na qual este teólogo compõe toda sua obra.

O segundo enfoque, filosófico, amplia o anterior. É o problema da verdade, a qual não pode ser separada da luta do povo e das esperanças e sonhos que se originam dessa luta. Embora nasça da subjetividade, diz o autor, a verdade não se reduz à subjetividade ${ }^{10}$. Apoiando-se nas contribuições da sociologia do conhecimento de Berger e Luckmann, Cone avoca Feuerbach, para quem "o pensamento é precedido pelo sofrimento" e Marx, que ensina: "Não é a consciência que determina a vida, mas é a vida que determina a consciência" ${ }^{11}$. Cone adota uma abordagem quase militante ao afirmar que a verdade não é um conceito ou uma ideia a ser descoberta num manual de teologia ou filosofia, mas é, antes, um evento libertador que, em função dessa característica, pode ser lido como um acontecimento divino na vida das pessoas ${ }^{12}$.

Aqui abre-se uma terceira abordagem, a teológica. Cone explora o caráter dinâmico da verdade, o que supõe a fé, que é risco na construção da vontade divina, a qual é indicativa e não impositiva e "não vem na forma de princípios absolutos aplicáveis a todas as situações, mas envolve o risco da fé".

Portanto, para Cone, isso significa que nem os oprimidos são infalíveis ${ }^{13}$. Porque a realidade é complexa, e não basta ser oprimido nem ter consciência de sofrer opressão para estar na verdade. Isto porque, a verdade e a fé precisam desembocar na ação comprometida. Por isso a presença de Deus se manifesta no caráter libertador de Jesus Cristo, que não apenas simpatizou com os fracos, mas se

\footnotetext{
${ }^{8}$ CONE, James H. O Deus dos oprimidos

${ }^{9}$ Ibidem, p. 5

${ }^{10}$ Ibidem, p. 116

${ }^{11}$ In op. cit. p. 19; BERGER, P., LUCKMANN, Th. A construção social da realidade

${ }^{12}$ CONE, op. cit. p. 263

${ }^{13}$ Ibidem, p. 224
} 
identificava totalmente com eles na agonia e na dor $^{14}$. A característica existencial de seu pensamento se explicita na ideia de que a teologia "é sempre interessada" e nasce da experiência pessoal e social de liberdade, no caso, do povo negro submetido à opressão. Daí ser possível a brancos - ao morrerem para os privilégios de sua branquitude e renascerem para a luta contra a opressão branca e para a libertação dos oprimidos - tomar um lugar na luta dos negros pela liberdade ${ }^{15}$.

Cone faz uma afirmação desconcertante para leitores não afinados com um pensar poético: "Jesus era judeu e, portanto, negro" 16 . Com isso propõe, ao invés de um enfoque de natureza étnica, uma negritude conceitual (embora concreta) a partir da condição histórica inarredável de Jesus, ao tomar o partido dos oprimidos. Essa é a base bíblica do autor, que dialoga com a teologia da esperança e explicitamente com o marxismo, fazendo severa crítica a uma teologia branca que, com louváveis exceções, espiritualiza Jesus e nega sua historicidade. Ao se pretender universal, a filosofia/teologia branca torna-se ideologia e contribui para o emudecimento de culturas de sociedades dizimadas:

A dizimação do povo vermelho e a escravização do povo negro feitas pelo povo branco na América do Norte é um exemplo da tentativa de privar um povo de suas estórias... não se permitiu que os escravos se comunicassem em suas línguas africanas ... o povo vermelho foi colocado em reservas ${ }^{17}$.

Uma quarta vertente na obra de Cone é a da sensibilidade artística. Ele está familiarizado com as formas de comunicação negra, tanto religiosa como profana (distinção que ele menciona, mas não adota), tanto bíblica quanto oriunda de outras religiões da África, Ásia e de outros lugares. Daí a frequência com que aproxima estórias e fábulas à pregação, blues ao gospel, dentro de um clima que mistura a adoração, o humor e o logro ante a dominação branca:

Somos um povo africano. Nossos avós trouxeram suas estórias e as combinaram com a estória cristã, criando assim uma tradição religiosa negra única na América do Norte. Não importa se a visão é recebida sábado à noite ou domingo de manhã ou se o intérprete da visão é o compositor de blues B.B. King ou o Rev. C.L. Franklin ${ }^{18}$.

\footnotetext{
${ }^{14}$ Ibidem, p. 190

15 Ibidem, p. 261

${ }^{16}$ Ibidem, p. 148

${ }^{17}$ Ibidem, p. 115

${ }^{18}$ Ibidem p. 126
} 
A denúncia da opressão na sociedade norte-americana é o foco do teólogo Richard Horsley, branco, professor na Massachusetts University. Biblista reconhecido, ele parte do contexto histórico e social na época de Jesus para traçar um paralelo com os EUA, país que se vê como a "Nova Roma". Tal identificação foi expressa por Thomas Jefferson e se insinua no estilo clássico dos prédios públicos de Washington, DC. Essa mentalidade aflorou no período pós-9/11/2001, quando a administração Bush e setores conservadores pediram as bênçãos de Jesus para algum tipo de retaliação. A ideia de que os EUA são um Império ungido por Deus já fora elaborada pelas igrejas tradicionais que aprovaram a anexação de territórios estrangeiros, atribuindo ao governo dos EUA o papel de missionário e, assim como elas, tem a missão de civilizar o resto do mundo. Horsley reconhece a influência, em sua trajetória intelectual, da Teologia da Libertação brasileira e latinoamericana $^{19}$.

\section{ATIVISMO, BANDEIRAS}

A TdL nos EUA tem inspirado muitas ações concretas. Nos anos 1970, o teólogo chileno Sérgio Torres organizou uma conferência ecumênica "Theology in the Americas", que ocorreu em Detroit e reuniu as tendências emergentes envolvidas com a solidariedade às mulheres, à luta contra as ditaduras na América Latina e contra o gigantesco encarceramento no país, sobretudo de negros. Nos anos 1980 a TdL foi aos poucos se confinando à Academia e se afastando dos movimentos sociais. Entretanto, há pessoas, grupos e publicações que mantêm viva essa tendência. Por exemplo, o jornal "Sojourners", editado em Washington pelo evangélico Jim Wallace, líder de comunidade vive entre os pobres e adota um enfoque pacifista. Também os anabatistas do Radical Discipleship, liderados por Ched Myers, com maioria branca, voltados para a promoção dos imigrantes sem documentos e identificados com temas como reconciliação e estudos bíblicos.

Atualmente uma "perspectiva da libertação" está disseminada nas bandeiras liberais presentes na cultura e mentalidade estadunidenses. Por exemplo, nos direitos dos gays, na recepção às falas e ideias de Cornel West $^{20}$, na luta contra o imperialismo e militarismo, contra o encarceramento e pela desativação da prisão de Guantánamo, nas pautas ecológicas lideradas por Bill McKibben, contra a avareza corporativa.

Referência obrigatória, a Orbis Books (pertencente à Congregação Maryknoll) desde os anos 1970 até o início da década de 1990 publicou praticamente todos os teólogos da libertação latino-

\footnotetext{
${ }^{19}$ HORSLEY, R. A. Jesus e o Império (passim)

${ }^{20}$ WEST, C. Questão de Raça
} 
americanos - Gustavo Gutierrez, Paulo Evaristo Arns, Jon Sobrino, Leonardo Boff, Pablo Richard, Elza Tamez, José Míguez Bonino, Pedro Casaldáliga, Carlos Mesters, Joseph Comblin, Ignacio Ellacuría. Atualmente, no entanto, o mercado para essa temática apresenta queda acentuada.

$\mathrm{Na}$ TdL católica, atualmente a não-violência é uma tendência central, embora apresente movimento pendular. Até a guerra do Vietnã, os pacifistas eram uma minoria; a partir daí, ganhou força e desembocou em forte reação antinuclear. Ao final da Guerra Fria, o pacifismo se dissipou; durante a Guerra do Golfo, de 1990, ainda ocorreram intensos protestos; entretanto, após os atentados de 11/9/2001, não houve grande reação às invasões do Iraque e Afeganistão, graças à manipulação do medo pelo governo Bush.

Em 17 de março de 2003, no dia de São Patrício, padroeiro da Irlanda e de seus descendentes nos EUA, ocorreu um episódio paradigmático, pouco divulgado: o “St. Patrick's Day Four”. Na ocasião, quatro pacifistas católicos de origem irlandesa jogaram o próprio sangue nas paredes, cartazes e na bandeira dos Estados Unidos num centro de recrutamento militar, na cidade de Ithaca. Eles pertenciam a movimentos como o Catholic Worker (criado pela ativista e escritora Dorothy Day), o Christian Peacemaker Teams e o Magnificat Catholic Worker. Os quatro protestavam contra a ameaça de invasão do Iraque (que começaria dali a três dias). Em seguida, ajoelharam-se e aguardaram ser presos.

Nos julgamentos que se seguiram, os quatro argumentaram que a invasão do Iraque era ilegal perante o direito internacional, por não ser aprovada pela ONU, e que os Princípios de Nurenberg os autorizam a agir em caso de crimes contra a humanidade. Diziam-se inspirados pela Boston Tea Party, por Rosa Parks e Martin Luther King. Segundo a professora Elizabeth Castelli, da Columbia University, o grande sacrilégio dos manifestantes foi jogar sangue na bandeira americana. Para ela, todo o episódio reúne dimensões que o tornam um capítulo típico da Teologia da Libertação ao estilo estadunidense.

\section{CONSIDERAÇÕES FINAIS}

Ultimamente, a TdL estadunidense começou a mudar seu estilo e temática, voltando-se para a crítica das estruturas econômicas e sociais, do Império e das injustiças. Um dos sinais disso é a presença de partidários da Teologia da Libertação no movimento Occupy Wall Street. Dentre os grupos mais prolíficos está a Teologia Latina/o e a Womanist. Essa teologia ainda mantém o estilo acadêmico, ainda mais radical em suas colocações teóricas. Também desenvolve estudos bíblicos com enfoque na libertação. 
Houve grande expectativa entre teólogos e intelectuais quanto à canonização de dom Oscar Romero (proclamada em 2018) na esteira da elevação do papa João XXIII, bem como a retomada do espírito do Vaticano II. É apontado um afastamento do estilo dos papas João Paulo II e Bento XVI, caracterizado pela ênfase na autoridade e culto à personalidade, pelo alijamento dos leigos, pela proteção ao establishment clerical e alienação das mulheres das estruturas superiores do catolicismo.

No campo católico estadunidense, as pautas específicas da TdL são a reação às atitudes dos bispos e a denúncia de abusos sexuais e falta de transparência nas decisões. O Papa Francisco suscitou grande otimismo por sua mudança de tom ao se dirigir aos fiéis, pela solidariedade, por gestos simbólicos de apoio à opção pelos pobres, pela atenuação da autorreferência e estímulo do encontro com os companheiros do mundo. Espera-se maior colegialidade nas decisões, que seja suspensa a intervenção sobre a Leadership Conference of Women Religious e que sejam promovidas mudanças paulatinas com a nomeação de bispos mais progressistas. Essas seriam medidas de como a Igreja Católica poderia enfrentar a atual crise de vocações, as amplas saídas de fiéis na direção do pentecostalismo do secularismo urbano.

Meu contato com representantes da TL negra inspira desdobramentos: Seria ela exclusiva da raça que lhe deu origem? Como encara os conflitos entre classes sociais próprio da TL latinoamericana? Quais as diferenças entre a TL católica e protestante? Diante da repressão da hierarquia católica, o protestantismo ofereceria maior liberdade e futuro para a TL? Qual a contribuição das teólogas, cujo ponto de partida é a situação das mulheres e, mais, das mulheres negras? Como a TL negra avalia a religião mainframe estadunidense, o neopentecostalismo? Essas questões abrem rumos para novas pesquisas e, inclusive, confrontam a realidade brasileira.

\section{REFERENCIAS}

ARNS, P. E. Brasil: Nunca Mais. Petrópolis: Vozes, 1985

BERGER, P. L. e LUCKMANN, T. A construção social da realidade: tratado de sociologia do conhecimento. Rio de Janeiro: Editora Vozes, 2004.

BOFF, L. Jesus Cristo Libertador: Petrópolis: Vozes, 2004

CARSON, C. Civil Rights Chronicle - the African-american struggle for freedom. Lincolnwood: Legacy, 2003.

COMBLIN, J. Em busca da liberdade. São Paulo: Paulus, 2007

CONE, J. H. O Deus dos oprimidos. São Paulo: Paulinas, 1985 
A Black Theology of Liberation. New York: Orbis Books, 1970

Black Theology and Black Power. New York: Orbis Books, 1969

The Cross and the Lynching Tree. New York: Orbis Books, 2011

DU BOIS, W.E.B. The souls of black folk. New York: Dover Publications, 1994

Dusk of Dawn. New York: Schoken, 1940

DUNAWAY, F. A Teologia Negra: uma Introdução (mimeo).

FREED, L. This is the Day - the march on Washington. Los Angeles: Getty Publications, 2013.

GUTIERREZ, G. Teologia da Libertação. São Paulo: Loyola, 2000

HORSLEY, R. A. Jesus e o Império. São Paulo: Paulus, 2004

RABOTEAU, A. Slave Religion. Oxford: Oxford Un. Press, 2004

SOBRINO, J. Fora dos pobres não há salvação. São Paulo: Paulinas, 2008

WALKER, Alice. A cor púrpura. Rio de Janeiro: José Olympio, 2009

WEST, C. Questão de Raça. São Paulo: Companhia das Letras, 1994 